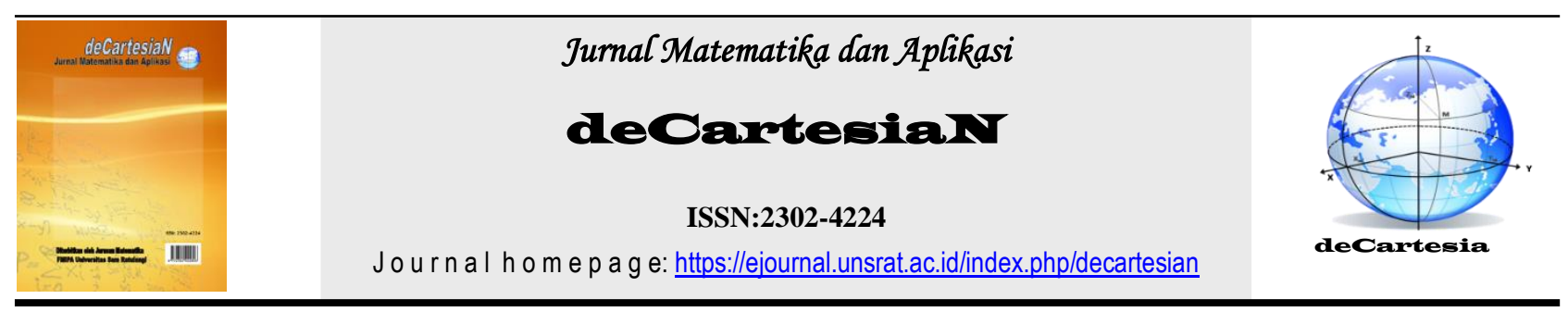

\title{
Optimasi Perencanaan Produksi Pada CV. Meubel Karya Nyata Gorontalo Menggunakan Model Program Linear Fuzzy
}

\author{
Mohamad Iqbal Pulukadang1, Yohanes A.R. Langi ${ }^{1}$, Altien J. Rindengan ${ }^{{ }^{*}}$ \\ ${ }^{1}$ Program Studi Matematika-Fakultas Matematika dan Ilmu Pengetahuan Alam-Universitas Sam Ratulangi, \\ Manado, Indonesia \\ *Corresponding author : altien@unsrat.ac.id
}

\begin{abstract}
A B S T R A K
Pengoptimalan merupakan salah satu proses untuk memanfaatkan sumber daya hingga batas tertinggi yang dapat digunakan untuk mencapai keuntungan yang maksimum. Penggunaan solusi optimum biasa digunakan oleh perusahaan yang bergerak pada bidang produksi atau pemasaran. Penelitian ini dilakukan bertujuan untuk mengoptimumkan produksi berdasarkan jumlah sumber daya yang tersedia dengan menggunakan model program linear fuzzy, yang dilakukan pada CV. Meubel Karya Nyata. Data yang digunakan merupakan data sumber daya pada bulan Maret 2018. Hasilnya menunjukkan untuk mengotimumkan produksi dengan keuntungan maksimal, maka perusahaan harus memproduksi lemari sebanyak 20 unit, kursi sebanyak 31 unit, dan tempat tidur sebanyak 1 unit dengan keuntungan sebesar Rp. 91.950.00o.
\end{abstract}

\section{INFORMASI ARTIKEL}

Diterima : 17 Juli 2018

Diterima setelah revisi : 23 Juli 2018

Tersedia online $\quad$ : 30 Juli 2018

\section{Kata Kunci:}

Perencanaan Produksi,

Optimasi,

Program Linear Fuzzy

\section{LATAR BELAKANG}

Perkembangan ilmu pengetahuan senantiasa mengalami kemajuan dari waktu ke waktu seiring dengan kebutuhan manusia yang senantiasa terus bertambah, baik dari kebutuhan kualitas, kenyamanan dan lain sebagainya. Kebutuhankebutuhan yang beraneka ragam tersebut menjadi permasalahan yang terjadi secara nyata di saat ini. Dalam kehidupan sehari-hari, pengambilan keputusan atas suatu masalah tidak bisa dengan jawaban sederhana yaitu "Ya" atau "Tidak". Sebagai contoh, untuk menyatakan seseorang berbadan "tinggi" atau "pendek" adalah bersifat relatif bagi orang satu dengan yang lainnya. Demikian juga untuk untuk menentukan rasa "manis" atau "pahit".

Menurut Kumala (2014), program linear adalah suatu cara untuk menentukan nilai optimum (maksismum atau minimum) dari suatu fungsi linear dibawah kendala-kendala tertentu yang dinyatakan dalam bentuk persamaan atau pertidaksamaan linear. Dimana setiap parameter data dalam program linear yang terdiri dari koefisien-koefisien fungsi tujuan, konstanta-konstanta sebelah kanan dan koefisien teknis, diketahui secara pasti. Sementara fakta yang muncul adalah hal-hal yang berhubungan dengan ilmu pengetahuan tidak selalu bersifat tegas dalam kehidupan sehari-hari [1]. Sehingga munculah suatu metode yang dapat digunakan untuk pemecahan masalah yang bersifat samar untuk perencanaan produksi, yaitu fuzzy linear Programming .
Beberapa penelitian telah dilakukan sebelumnya, antara lain, model fuzzy goal programming yang diselesaikan dengan linear programming [2]. Kemudian aplikasi fuzzy goal programming (Studi Kasus: UD. Sinar Sakti Manado) [3].

Dalam penelitian yang dilakukan ini, akan di bahas mengenai optimasi perencanaan produksi menggunakan model fuzzy linear programming pada CV. Meubel Karya Nyata Gorontalo.

\section{TEORI FUZZY}

\subsection{Logika Fuzzy}

Pada tahun 1965, Prof. Lofti A. Zadeh dari California University USA memberikan sumbangan yang berharga dalam pengembangan teori himpunan fuzzy (samar). Dalam kamus Oxford, istilah fuzzy didefinisikan sebagai blurred (kabur atau remangremang), indistinct (tidak jelas), imprecisely defined (didefinisikan secara tidak presisi), confused (membingungkan), vague (tidak jelas). Penggunaan istilah "sistem fuzzy" tidak dimaksudkan untuk mengacu pada sebuah sistem yang tidak jelas/kabur/remang-remang definisinya, cara kerjanya, atau deskripsinya. Sebaliknya, yang dimaksud dengan sistem fuzzy adalah sebuah sistem yang dibangun dengan definisi, cara kerja, dan deskripsi yang jelas berdasar pada teori fuzzy logic. Logika fuzzy adalah suatu cara yang tepat untuk 
memetakan suatu ruang input ke dalam suatu ruang output [4].

\subsubsection{Himpunan Fuzzy}

Ada beberapa hal yang perlu diketahui dalam memahami himpunan fuzzy, yaitu:

a. Variabel fuzzy

Variabel fuzzy merupakan suatu lambang atau kata yang menunjuk kepada suatu yang tidak tertentu dalam sistem fuzzy.

Contoh: permintaan, persediaan, produksi, dan sebagainya.

b. Himpunan fuzzy

Himpunan fuzzy merupakan suatu kumpulan yang mewakili suatu kondisi atau keadaan tertentu dalam suatu variabel fuzzy.

c. Semesta pembicaraan

Semesta pembicaraan adalah keseluruhan nilai yang diperbolehkan untuk dioperasikan dalam suatu variabel fuzzy.

d. Domain

Domain himpunan fuzzy adalah keseluruhan nilai yang diijinkan dalam semesta pembicaraan dan boleh dioperasikan dalam suatu himpunan fuzzy [5].

\subsubsection{Fungsi Keanggotaan}

Dalam logika tegas, fungsi keanggotaan menyatakan keanggotaan pada suatu himpunan. Fungsi kenaggotaan $X_{A}(x)$ bernilai 1 jika $x$ anggota himpunan $\mathrm{A}$, dan bernilai o jika $x$ bukan anggota himpunan A. Jadi fungsi keanggotaan ini hanya bisa bernilai 0 atau 1 .

$$
X_{A}(x) \rightarrow\{0,1\}
$$

Sedangkan dalam logika fuzzy, fungsi keanggotaan menyatakan derajat keanggotaan pada suatu himpunan. Nilai dari fungsi keanggotaan ini berada dalam selang $[0,1]$ dan dinyatakan dengan $\mu_{A}$.

$$
\mu_{A}: x \rightarrow[0,1]
$$

Fungsi keanggotaan $\mu_{A}(x)$ bernilai 1 jika $x$ anggota penuh himpunan $A$ dan bernilai o jika $x$ bukan anggota himpunan $A$. Sedangkan jika derajat keanggotaan berada dalam selang [0,1], misalnya $\mu_{A}(x)=\mu$, menyatakan $x$ sebagian anggota himpunan $A$ dengan derajat keanggotaan sebesar $\mu[6]$.

Fungsi keanggotaan himpunan fuzzy dapat ditentukan dengan fungsi linear, segitiga dan trapesium.

Representasi linear naik, yaitu kenaikan himpunan dimulai dari nilai domain yang memiliki nilai keanggotaan nol [o] bergerak ke kanan menuju ke nilai domain yang memiliki derajat keanggotaan yang lebih tinggi[4].

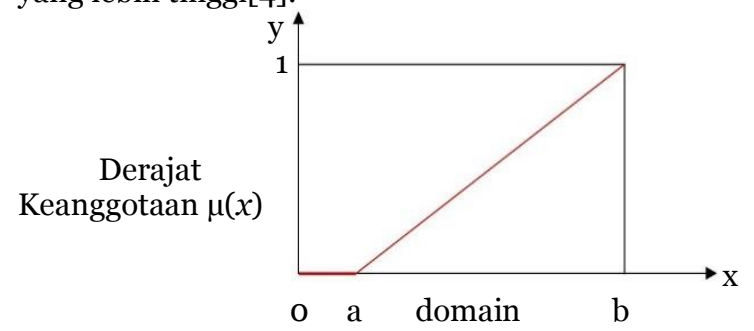

Gambar 1. Representasi linear naik

Fungsi keanggotaan:

$$
\mu(x)=\left\{\begin{array}{cl}
0 & ; x \leq 0 \\
\frac{(x-a)}{(b-a)} ; & a<x \leq b
\end{array}\right.
$$

\subsection{Program Linear Fuzzy}

Pemrograman linear adalah suatu cara menyelesaikan persoalan pengalokasian sumbersumber yang terbatas di antara beberapa aktivitas yang bersaing, dengan cara yang terbaik yang mungkin dilakukan. Persoalan pengalokasian ini akan muncul manakala seseorang harus memilih tingkat aktivitas-aktivitas tertentu yang bersaing dalam hal penggunaan sumber daya langka yang dibutuhkan untuk melaksanakan aktivitas tersebut [5].

\subsubsection{Model Program Linear}

Model matematika perumusan masalah umum pengalokasian sumber daya untuk berbagai kegiatan, disebut model program linear. Model ini merupakan bentuk dan susunan dalam menyajikan masalah-masalah yang akan dipecahkan dengan teknik pemrograman linear [7].

Dengan demikian dapat di formulasi model matematis dari persoalan pengalokasian sumbersumber pada aktifitas-aktifitas sebagai berikut: Maksimumkan (minimumkan) : $Z=c_{1} x_{1}+c_{2} x_{2}+$ $\cdots+c_{j} x_{j}$

$$
=\sum_{j=1}^{n} c_{j} x_{j}
$$

Dengan syarat :

$\sum_{i=1}^{m} a_{i j} x_{j}(\leq,=, \geq) b_{i}$, untuk semua $i=1,2, \ldots, m$ dan, $x_{n}$

Dimana :$$
\geq 0
$$

$x_{j}=$ tingkat kegiatan ke-j, dimana $\mathrm{j}=1,2, \ldots \mathrm{n}$

$Z$ = nilai yang dioptimalkan

$c_{j}=$ sumbangan per unit untuk kegiatan $\mathrm{j}$

$b_{i}=$ jumlah sumber daya ke-i

$a_{i j}=$ banyaknya sumber daya ke-i

$m=$ macam batasan sumber atau fasilitas yang tersedia

$n$ =macam kegiatan-kegiatan yang menggunakan sumber daya atau fasilitas tersebut

$i$ = macam-macam sumber atau fasilitas yang ada

\subsubsection{Model Program Linear Fuzzy}

Program linear fuzzy adalah suatu model yang digunakan untuk mencari nilai $\mathrm{Z}$ yang merupakan fungsi obyektif yang akan dioptimasikan sedemikian hingga tunduk pada batasan-batasan yang dimodelkan denga menggunakan himpunan fuzzy [8]. Pada penelitian ini masalah yang akan dibahas adalah masalah maksimasi. Model matematis dari permasalahn maksimasi sebagai berikut:

Tentukan $\mathrm{x}$ sedemikian hingga:

$$
\begin{aligned}
& c^{T} x \geq z \\
& A x \leq b \\
& X \geq 0
\end{aligned}
$$

Bentuk persamaan di atas dapat dapat dibawa kedalam bentuk persamaan sebagai berikut:

$$
\begin{aligned}
& B x \leq d \\
& x \geq 0
\end{aligned}
$$

dengan : 


$$
\begin{aligned}
& B=\left(\begin{array}{c}
-c \\
A
\end{array}\right) ; \text { dan } \\
& d=\left(\begin{array}{c}
-d \\
Z
\end{array}\right)
\end{aligned}
$$

Tiap-tiap baris/batasan $(1,2,3, \ldots, m)$ akan direpresentasikan dengan sebuah himpunan fuzzy, dengan fungsi keanggotaan pada himpunan ke-i adalah $\mu_{i}\left[B_{i} x\right]$. Fungsi keanggotaan model keputusan himpunan fuzzy dapat dinyatakan sebagai :

$$
\mu_{D}[x]=\min _{i}\left\{\mu_{i}\left[B_{i} x\right]\right\}
$$

Tentu saja diharapkan kita akan mendapatkan solusi terbaik, yaitu suatu solusi dengan nilai keanggotaan yang paling besar, dengan demikian solusi sebenarnya adalah:

$$
\max _{x \geq 0} \mu_{D}[B x]=\max _{x \geq 0} \min _{i}\left\{\mu_{i}\left[B_{i} x\right]\right\}
$$

Dari sini terlihat bahwa $\mu_{i}\left[B_{i} x\right]=0$ jika batasan ke-i benar-benar dilanggar. Sebaliknya, $\mu_{i}\left[B_{i} x\right]=1$ jika batasan ke- $i$ benar-benar dipatuhi. Nilai $\mu_{i}\left[B_{i} x\right]$ akan naik secara monoton pada selang [o,1], yaitu:

$$
\mu_{i}\left[B_{i} x\right]=\left\{\begin{array}{cc}
1 ; & \text { jika } B_{i} x \leq d_{i} \\
1-\frac{B_{i} x-d_{i}}{p_{i}} ; & \text { jika } d_{i}<B_{i} x \leq d_{i}+p_{i} \\
0 ; & \text { Jika } B_{i} x>d_{i}+p_{i}
\end{array}\right.
$$

Dengan $p_{i}$ adalah toleransi interval yang diperbolehkan untuk melakukan pelanggaran baik pada fungsi obyektif maupun batasan.

Untuk mencari nilai $\lambda$-cut dapat dihitung sebagai $\lambda=1-t$, dengan:

$$
d_{i}+p_{i}=\text { ruas kanan batas ke }-i
$$

Nilai $t$ merupakan skala yang di gunakan untuk menentukan jumlah penambahhan terbesar dari setiap batasan yang di ijinkan. Sedangkan $\lambda$ merupakan nilai yang digunakan untuk mengimplementasikan setiap batasan.

Dengan demikian diperoleh bentuk linear programming baru sebagai berikut:

Maksimumkan : $\lambda$

Kendala $: \lambda p_{i}+B_{i} x \leq d_{i}+p_{i} ; \quad \mathrm{i}=0,1,2, \ldots, \mathrm{m}$

$$
\mathrm{x} \geq 0
$$

\section{METODOLOGI PENELITIAN}

\subsection{Waktu dan Tempat Penelitian}

Penelitian ini dilaksanakan selama bulan Januari 2018 sampai bulan Maret 2018, mulai dari penyusunan proposal, pegambilan data serta pengolahan data. Pengambilan data dilakukan di CV. Meubel Karya Nyata Gorontalo dan pengolahan data dilakukan di Laboratorium Komputer Dasar, Fakultas Matematika dan Ilmu Pengetahuan Alam, Universitas Sam Ratulangi Manado.

\subsection{Analisis Data}

Analisis data pada penelitian ini menggunakan Fuzzy Linear Programing .

Langkah-langkah analisis data Fuzzy Linear Programing, yaitu:

1. Pengambilan Data

Data yang akan digunakan pada penelitian ini merupakan data pada bulan agustus 218 yang akan di ambil di CV. Meubel Larya Nyata.

2. Membuat Model Linear Programming

Membuat model berdasarkan data yang telah diambil yaitu menentukan fungsi tujuan dan fungsi kendala. Pada pembuatan model ini, jenis produk Lemari, kursi dan Tempat tidur akan menjadi variabel $x_{1}, x_{2}$ dan $x_{3}$ yang akan di maksimumkan sebagai fungsi tujuan. Sementara bahan baku, jam kerja dan jumlah pekerja akan menjadi fungsi kendala.

3. Penambahan Nilai Toleransi Pada Model

Penambahan nilai toleransi pada model dimaksudkan sebagai batasan fuzzy .

4. Penyelesain Model Linear Programming

Model yang telah di buat akan diselesaikan menggunakan software POM-QM for Windows 3 .

5. Batasan Fuzzy

Merupakan nilai yang di dapatkan dari penyelsaian model linear programming.

6. Model Fuzzy Linear Programming

Model fuzzy linear programming dibentuk berdasarkan fungsi kendala yang ada dan ditambahkan dengan niali batasan fuzzy

7. Penyelesaian Model Fuzzy Linear Programming Penyelesaian Fuzzy Linear Programming dilakukan dengan menggunakan software POMQM for Windows 3.

\section{HASIL DAN PEMBAHASAN}

\subsection{Pengumpulan Data}

Data pada penelitian ini, di ambil dari CV. Meubel Karya Nyata. Data yang ambil adalah bahan baku produksi di bulan Maret 2018. Berdasarkan data yang telah di dapatkan, maka di bentuk tabel produksi sebagai berikut :

Tabel 1. Data bahan baku produksi

\begin{tabular}{|l|c|c|c|c|c|}
\hline \multirow{2}{*}{ Bahan Baku } & \multicolumn{3}{|c|}{ Produk } & \multicolumn{2}{c|}{ Kapasitas } \\
\cline { 2 - 6 } & Lemari & Kursi & Tempat Tidur & Maksimum & Toleransi \\
\hline Papan $\left(\mathrm{m}^{2}\right)$ & 9,6 & 7,2 & 12 & 480 & 60 \\
\hline Cat $(\mathrm{L})$ & 3 & 2 & 2 & 100 & 50 \\
\hline Tiner $(\mathrm{L})$ & 2 & 2 & 2 & 90 & 30 \\
\hline Amplas $(\mathrm{m})$ & 1 & 1 & 1 & 50 & 30 \\
\hline Lem $(\mathrm{Kg})$ & 1 & 1 & 1 & 50 & 30 \\
\hline $\begin{array}{l}\text { Waktu } \\
\text { Proses I }\end{array}$ & 12 & 9 & 12 & 720 & 0 \\
\hline $\begin{array}{l}\text { Waktu } \\
\text { Proses II }\end{array}$ & 9 & 6 & 8 & 720 & 0 \\
\hline Harga/unit & 2.000 .000 & 1.600 .000 & 1.550 .000 & & \\
\hline
\end{tabular}

Jam proses I meliputi pemotongan papan hingga perakitan dan jam proses II meliputi pengamplasan pengecetan dan pengeringan. Dengan jumlah produksi minimum kursi sebanyak 2 unit, kursi sebanyak 2 unit dan tempat tidur sebanyak 1 unit.

\subsection{Formulasi Model}

- Variabel keputusan

Variabel keputusan merupakan variabel yang akan dicari nilai tingkat kegiatan berdasarkan sumber daya yang ada. Berdasarkan data diatas, maka variabel keputusan untuk permasalahannya adalah sebagai berikut :

$x_{1}=$ Jumlah lemari yang di produksi

$x_{2}=$ Jumlah kursi yang di produksi

$x_{3}=$ Jumlah tempat tidur yang di produksi

- Fungsi Kendala

Fungsi kendala adalah bentuk fungsi pertidaksamaan ataupun persamaan yang menyatakan jumlah dari tingkat kegiatan yang dibatasi oleh banyaknya sumber daya yang 
tersedia. Dari tabel data bahan baku produksi, maka fungsi kendalanya adalah :

1. Papan :9,6 $6 x_{1}+7,2 x_{2}+12 x_{3} \leq 480+60 t$

2. Cat $: 3 x_{1}+2 x_{2}+2 x_{3} \leq 100+50 t$

3. Tiner $: 2 x_{1}+2 x_{2}+2 x_{3} \leq 90+30 t$

4. Amplas : $x_{1}+x_{2}+x_{3} \leq 50+30 t$

5. Lem $\quad: x_{1}+x_{2}+x_{3} \leq 50+30 t$

6. Waktu proses I : $12 x_{1}+9 x_{2}+12 x_{3} \leq 720$

7. Waktu proses II : $9 x_{1}+6 x_{2}+8 x_{3} \leq 720$

8. Jumlah minimal lemari yang di produksi :

$$
x_{1} \geq 2
$$

9. Jumlah minimal lemari yang di produksi :

$$
x_{2} \geq 2
$$

10. Jumlah minimal lemari yang di produksi :

$$
x_{3} \geq 1
$$

- Fungsi Tujuan

Fungsi tujuan merupakan fungsi yang akan ditentukan nilai maksimum atau minimumnya. Nilai fungsi tujuan sendiri bergantung pada kontribusi per unit untuk setiap variabel keputusan. Dengan melihat data di atas, maka bentuk fungsi tujuannya adalah :

Maksimumkan :

$Z=2000000 x_{1}+1600000 x_{2}+1550000 x_{3}$ Selanjutnya, berdasarkan data diatas, maka formulasi lengkapnya adalah :

Maksimumkan :

$$
Z=2000000 x_{1}+1600000 x_{2}+1550000 x_{3}
$$

Dengan Batasan

$$
\begin{aligned}
9,6 x_{1}+7,2 x_{2}+12 x_{3} & \leq 480+60 t \\
3 x_{1}+2 x_{2}+2 x_{3} & \leq 100+50 t \\
2 x_{1}+2 x_{2}+2 x_{3} & \leq 90+30 t \\
x_{1}+x_{2}+x_{3} & \leq 50+30 t \\
x_{1}+x_{2}+x_{3} & \leq 50+30 t \\
12 x_{1}+9 x_{2}+12 x_{3} & \leq 720 \\
9 x_{1}+6 x_{2}+8 x_{3} & \leq 720 \\
x_{1} & \geq 2 \\
x_{2} & \geq 2 \\
x_{3} & \geq 1 \\
& x_{1}, x_{2}, x_{3} \geq 0
\end{aligned}
$$

\subsection{Penyelesaian dengan Program Linear}

Selanjutnya dengan menggunakan metode simpleks, akan di cari nilai batasan fuzzy berdasarkan formulasi masalah yang telah di buat.

Dari formulasi tersebut, akan di cari keuntungan maksimum . Untuk $t=0(\lambda=1)$, diperoleh model :

Maksimumkan :

$$
Z=2000000 x_{1}+1600000 x_{2}+1550000 x_{3}
$$

Dengan Batasan :

$$
\begin{aligned}
& 9,6 x_{1}+7,2 x_{2}+12 x_{3} \leq 480+60 t \\
& 3 x_{1}+2 x_{2}+2 x_{3} \leq 100+50 t \\
& 2 x_{1}+2 x_{2}+2 x_{3} \leq 90+30 t \\
& x_{1}+x_{2}+x_{3} \leq 50+30 t \\
& x_{1}+x_{2}+x_{3} \leq 50+30 t \\
& 12 x_{1}+9 x_{2}+12 x_{3} \leq 720 \leq 72 \\
& 9 x_{1}+6 x_{2}+8 x_{3} \leq 720 \\
& x_{1} \geq 2 \\
& x_{2} \geq 2 \\
& x_{3} \geq 1 \\
& x_{1}, x_{2}, x_{3} \geq 0 \\
& \text { Memberikan solusi: } \\
& x_{1}=10 \\
& x_{2}=35
\end{aligned}
$$

$x_{3}=1$

$Z=75950000$

Dari solusi di atas, masih terdapat bahan baku yang tersisa dari proses produksi, yaitu:

Tabel 2. Sisa bahan baku pada Non Fuzzy

\begin{tabular}{|c|c|c|}
\hline Bahan Baku & Terpakai & Sisa \\
\hline Papan & 352,8 & 127,8 \\
\hline Cat & 100 & 0 \\
\hline Tiner & 90 & 0 \\
\hline Amplas & 45 & 5 \\
\hline Lem & 45 & 5 \\
\hline Waktu proses I & 438 & 282 \\
\hline Waktu Proses II & 302 & 418 \\
\hline
\end{tabular}

Untuk $t=1(\lambda=0)$, diperoleh model :

Maksimumkan:

$$
Z=2000000 x_{1}+1600000 x_{2}+1550000 x_{3}
$$

Dengan batasan :

$$
\begin{aligned}
9,6 x_{1}+7,2 x_{2}+12 x_{3} & \leq 540 \\
3 x_{1}+2 x_{2}+2 x_{3} & \leq 150 \\
2 x_{1}+2 x_{2}+2 x_{3} & \leq 120 \\
x_{1}+x_{2}+x_{3} & \leq 80 \\
x_{1}+x_{2}+x_{3} & \leq 80 \\
12 x_{1}+9 x_{2}+12 x_{3} & \leq 720 \\
9 x_{1}+6 x_{2}+8 x_{3} & \leq 720 \\
x 1 \quad \geq 2 & \geq 2 \\
x_{2} & \geq 1 \\
x_{3} \geq &
\end{aligned}
$$

Memberikan solusi :

$$
\begin{aligned}
& x_{1}=30 \\
& x_{2}=29 \\
& x_{3}=1 \\
& Z=107950000
\end{aligned}
$$

Dari kedua hasil ini $(t=1$ dan $t=0)$, dapat ditentukan nilai $P_{0}$, yaitu hasil penguragan dari $\mathrm{Z}$ pada saat $t=1$ dengan $\mathrm{Z}$ pada saat $t=0$.

$$
P_{0}=107950000-75950000=32000000
$$

\subsection{Penyelesaian dengan Fuzzy Linear Programming}

Setelah menyelesaikan formulasi dengan program linear, maka didapatkan batasan-batasan fuzzy:

Tabel 3. Batasan-batasan Fuzzy

\begin{tabular}{|c|c|c|}
\hline \multirow{2}{*}{} & \multicolumn{2}{|c|}{ Batasan-batasan Fuzzy } \\
\cline { 2 - 3 } & $\mathrm{t}=\mathrm{o}$ & $\mathrm{t}=1$ \\
\hline Fungsi Objektif & 75950000 & 107950000 \\
\hline Batasan 1 & 480 & 540 \\
\hline Batasan 2 & 100 & 150 \\
\hline Batasan 3 & 90 & 120 \\
\hline Batasan 4 & 50 & 80 \\
\hline Batasan 5 & 50 & 80 \\
\hline
\end{tabular}

Dengan batasan $\lambda=1-t$, dan $d_{i}+p_{i}=$ ruas kanan batas ke $-i$, akhirnya dapat di bentuk model program linear fuzzy, yaitu:

Maksimumkan $: \lambda$

Dengan batasan :

$32000000 \lambda-2000000 x_{1}-1600000 x_{2}-1550000 x_{3}$ $\leq-75950000$

$60 \lambda+9,6 x_{1}+7,2 x_{2}+12 x_{3} \leq 540$ 


$$
\begin{aligned}
& 50 \lambda+3 x_{1}+2 x_{2}+2 x_{3} \leq 150 \\
& 30 \lambda+2 x_{1}+2 x_{2}+2 x_{3} \leq 120 \\
& 30 \lambda+x_{1}+x_{2}+x_{3} \leq 80 \\
& 30 \lambda+x_{1}+x_{2}+x_{3} \leq 80 \\
& 12 x_{1}+9 x_{2}+12 x_{3} \leq 720 \\
& 9 x_{1}+6 x_{2}+8 x_{3} \leq 720 \\
& x_{1} \quad x_{2} \geq 2 \geq 2 \\
& x_{2} \quad x_{3} \geq 1 \\
& \lambda, x_{1}, x_{2}, x_{3} \geq 0
\end{aligned}
$$

Agar ruas kanan formulasi diatas tidak mempunyai nilai negatif, maka formulasi bentuk linear programming di atas di ubah menjadi :

Maksimumkan

Dengan Batasan :

$$
-32000000 \lambda+2000000 x 1+1600000 x 2
$$

$$
\begin{aligned}
& \begin{aligned}
&+1550000 x 3 \\
& 60 \lambda+9,6 x_{1}+7,2 x_{2}+12 x_{3} \leq 540
\end{aligned} \\
& 50 \lambda+3 x_{1}+2 x_{2}+2 x_{3} \leq 150 \\
& 30 \lambda+2 x_{1}+2 x_{2}+2 x_{3} \leq 120 \\
& 30 \lambda+x_{1}+x_{2}+x_{3} \leq 80 \\
& 30 \lambda+x_{1}+x_{2}+x_{3} \leq 80 \\
& 12 x_{1}+9 x_{2}+12 x_{3} \leq 720 \\
& 9 x_{1}+6 x_{2}+8 x_{3} \leq 720 \\
& x_{1} \quad \geq 2 \\
& \begin{array}{lll}
x_{2} \quad & \geq 2 \\
\quad x_{3} \geq 1
\end{array} \\
& \lambda, x_{1}, x_{2}, x_{3} \geq 0
\end{aligned}
$$

Kemudian formulasi ini di selesaikan menngunakan metode simpleks yang di hitung menggunakan software POM QM for Windows 3.

Setelah dilakukan perhitungan, memberikan solusi :

$$
\begin{gathered}
\lambda=0,5 \\
x_{1}=20 \\
x_{2}=31,5 \\
x_{3}=1 \\
Z=91950000
\end{gathered}
$$

Dari solusi di atas, masih terdapat bahan baku yang tersisa dari proses produksi, yaitu:

Tabel 4. Sisa bahan baku pada Fuzzy

\begin{tabular}{|c|c|c|}
\hline Bahan Baku & Terpakai & Sisa \\
\hline Papan & 430,8 & 109,2 \\
\hline Cat & 125 & 25 \\
\hline Tiner & 105 & 15 \\
\hline Amplas & 52,5 & 27,5 \\
\hline Lem & 52,5 & 27,5 \\
\hline Waktu proses I & 535,5 & 184,5 \\
\hline Waktu Proses II & 377 & 343 \\
\hline
\end{tabular}

\subsection{Pembahasan}

Berdasarkan hasil analisis di atas, solusi model program linear fuzzy dan model program linear biasa, dapat di lihat pada tabel berikut :

Tabel 5. Solusi Non-Fuzzy dan Fuzzy

\begin{tabular}{|c|c|c|}
\hline Variabel & Solusi Non-Fuzzy & Solusi Fuzzy \\
\hline$x_{1}$ & 10 & 20 \\
$x_{2}$ & 34 & 31,5 \\
$x_{3}$ & 1 & 1 \\
\hline$Z$ & 75950000 & 91950000 \\
\hline Bahan Baku & \multicolumn{2}{|c|}{ Nilai Batasan } \\
\hline
\end{tabular}

\begin{tabular}{|c|c|c|}
\hline Papan & 352,8 & 430,8 \\
Cat & 100 & 125 \\
Tiner & 90 & 100 \\
Amplas & 45 & 52,5 \\
Lem & 45 & 52,5 \\
Waktu Proses I & 438 & 535,5 \\
Waktu proses II & 302 & 377 \\
\hline$\lambda-$ cut & & 0,5 \\
\hline
\end{tabular}

Apabila menggunakan fuzzy linear programming $(\lambda=0,5)$, pendapatan maksimum akan diperoleh jika Lemari diproduksi sebanyak 20 unit, Kursi diproduksi sebanyak 31 unit dan Tempat tidur diproduksi sebanyak 1 unit, keuntungan yang diproleh (Z) sebesar Rp. 91.950.00o (Rp. 16.000.000 lebih banyak dibanding dengan linear programming biasa). Dengan catatan bahwa pada kondisi ini, dibutuhkan papan sebesar 430,8 $\mathrm{m}^{2}$, cat sebanyak 125 L, tiner sebanyak $105 \mathrm{~L}$, amplas sebanyak $52,5 \mathrm{~m}$, lem sebesar 52,5 Kg, jam proses I selama 535,5 jam, dan jam proses II selama 377 jam. Hasil ini mengharuskan penambahan cat sebanyak $25 \mathrm{~L}$ dari $100 \mathrm{~L}$ yang disediakan, tiner sebanyak $15 \mathrm{~L}$ dari $90 \mathrm{~L}$ yang bisa disediakan, amplas sebanyak $2,5 \mathrm{Kg}$ dari $50 \mathrm{Kg}$ yang bisa disediakan, dan lem sebesar 2,5 $\mathrm{m}$ dari $50 \mathrm{~m}$ yang bisa disediakan.

Sementara untuk nilai $\lambda=0,5$ mengandung makna bahwa $\lambda$-cut untuk setiap himpunan yang digunakan untuk mengimplementasikan setiap batasan sebesar 0,5 . Dengan kata lain, skala terbear $t=1-0,5=0,5$ digunakan untuk menentukan besarnya penambahan terbesar dari setiap batasan yang di ijinkan. Pada batasan-1, penambahan papan di ijinkan hingga 60 $\mathrm{m}^{2}$, pada kenyataannya penambahan yang dibutuhkan maksimal hanya sebesar $0,5 \times 60 \mathrm{~m}^{2}=$ $30 \mathrm{~m}^{2}$. Pada batasan-2, cat di ijinkan hingga $30 \mathrm{~L}$, namun kenyataannya penambahan yang dibutuhkan hanya sebesar $25 \mathrm{~L}$, untuk tiner hanya membutuhkan penambahan sebanyak $15 \mathrm{~L}$, amplas membutuhkan penambahan sebanyak $15 \mathrm{Kg}$ dan lem hanya membutuhkan penambahan sebesar $15 \mathrm{~m}$.

\section{KESIMPULAN}

Model fuzzy linear programming mempunyai hasi dengan solusi optimall $x_{1}=20, x_{2}=$ 31,5 , dan $x_{3}=1$ dengan keuntungan Rp. 91.950.000.

\section{Referensi}

[1] Haryati, E. 2011. Proses Untuk Menyelesaikan Masalah Full Fuzzy Linear Programming[skripsi]. Fakultas Matematika dan Ilmu Pengetahuan Alam Universitas Negeri Yogyakarta. Yogyakarta.

[2] Rindengan, A.J., P.T. Supriyo, dan A. Kustiyo. 2013. Model Fuzzy Goal Programming Yang Diselesaikan Dengan Linear Programming Pada Perencanaan Produksi. Jurnal de Cartesian. 2(2) : 26-32.

[3] Tampinongkol, F.F., A.J. Rindengan, dan L.A. Latumakulita. 2015. Aplikasi Fuzzy Goal Programming (Studi Kasus : UD. Sinar Sakti Manado). Jurnal de Cartesian. 4(2) : 129-137. 
[4] Kumala, W. 2014. Prosedur Program Linear Fuzzy Untuk Optimasi Perencanaan Produksi [skripsi]. Fakultas Sains dan Teknologi Universitas Maulana Malik Ibrahim. Malang.

[5] Silikin, F. 2011. Aplikasi Logika Fuzzy Dalam Optimasi Produksi Barang Menggunakan Metode Mamdani dan Metode Sugeno (studi kasus pada industri tahu H. Muadi) [Skripsi]. Fakultas Matematika dan Ilmu Pengetahuan Alam Universitas Negeri Yogyakarta. Yogyakarta.

[6] Kusumadewi, S. 2002. "Analisis dan Desain Sistem Fuzzy Menggunakan Toolbox Matlab”. Graha Ilmu. Yogyakarta.

[7] Munadziroh, L. 2008. Metode NonArchimedean Goal Programming Untuk Menyelesaikan Multiobjektif Linear Programming [skripsi]. Fakultas Sains dan Teknoligi Universitas Negeri Malang. Malang.

[8] Kusumadewi, S dan H. Purnomo. 2004. "Aplikasi Logika Fuzzy Untuk Pendukung Keputusan Edisi 1”. Graha Ilmu. Yogyakarta.

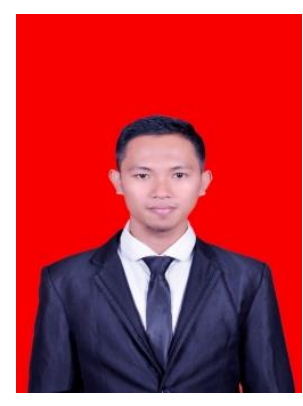

Mohamad Iqbal Pulukadang (mohamadiqbalpulukadang@gma il.com) Lahir di Paguat, Boalemo, Gorontalo, Indonesia. Belajar di Fakultas Matematika dan Ilmu Pengetahuan Alam Universitas Sam Ratulangi Manado. Tahun 2018 adalah tahun terakhirnya menduduki jenjang belajar di perguruan tinggi. Jurnal ini adalah publikasi dari penelitian yang dilaksanakan.
Yohanes A.R. Langi (yarlangi@unsrat.ac.id)

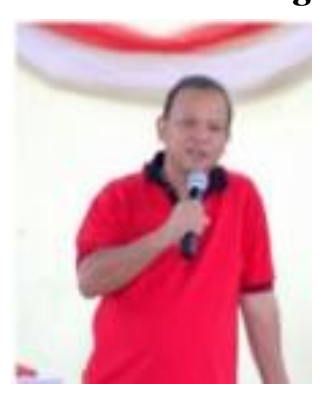
Pada tahun1994, memperoleh gelar sarjana di departemen Matematika, Fakultas Matematika dan Ilmu pengetahuan Alam, Universitas Kristen Tomohon. Gelar Magister bidang Biometrika Hutan diperoleh dari departemen Biometrika, Intitut Pertanian Bogor pada tahun 2007. Menjadi dosen di Departemen Matematika, Fakultas Matematika dan Ilmu Pengetahuan Alam, Universitas Samratulangi Manado, Sejak tahun2005 sampai sekarang.

Altien J. Rindengan (altien@unsrat.ac.id)

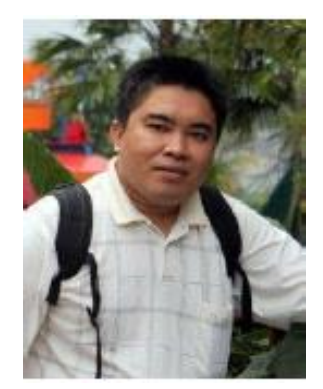
Pada tahun 1999 memperoleh gelar Sarjana di Departemen Matematika, Fakultas Matematikan dan Ilmu Pengetahuan Alam, Institut Pertanian Bogor. Gelar Magister Ilmu Komputer diperoleh dari Departemen Ilmu Komputer, Institut Pertanian Bogor, pada tahun 2012. Sejak tahun 2001 menjadi pengajar di jurusan Matematika, Fakultas Matematika dan Ilmu Pengetahuan Alam, Universitas Sam Ratulangi Manado. Fokus penelitian-penelitian yang dilakukan adalah Riset Operasi, Sistem Pendukung Keputusan, Sistem Fuzzy, Image Proccesing. 